Special issue of the International Conference on Computational and Experimental Science and Engineering (ICCESEN 2014)

\title{
Determination of Geomorphological Parameters of Damlica Basin Using GIS
}

\author{
A.Y. GÜNAL*, A. GÜVEN \\ Gaziantep University, Civil Engineering Department, Gaziantep, Turkey
}

\begin{abstract}
In this study, the geomorphologic parameters of Damlıca basin are determined by using Geographic Information Systems (GIS). The digital elevation model (DEM) of the basin is downloaded from Aster-GDEM web page and this digital map is used in the GIS computer program to obtain the geomorphologic parameters of the Damlica basin, such as the area of the basin, its perimeter, river length, slope, etc. The extracted parameters are compared with the parameters obtained by conventional methods. This study shows that the geomorphologic parameters of the Damlica basin obtained using GIS are much more precise than those produced by conventional methods.
\end{abstract}

DOI: 10.12693/APhysPolA.128.B-222

PACS: $92.40 . \mathrm{Pb}$

\section{Introduction}

Geographic information system (GIS) technique is a powerful tool that enables planners and decision makers to address current problems and future challenges effectively. There are many studies on GIS in the literature. GIS were used to make morphometric analysis of debris flows and their source areas [1], to make a spatially distributed model for runoff routing [2], to estimate the instantaneous unit hydrograph by Clark's method [3], to estimate geomorphologic parameters of lower Zab river basin [4], or to study the integrated hydrological modelling and GIS in water resources management [5].

Understanding hydrologic and geomorphologic characteristics of the region under study and preparing the required hydrologic and climatic datasets is a very important step in watershed planning and management. Watershed characteristics, such as area, length, slope, shape, surface roughness, soil type, vegetation and land cover, need to be calculated precisely before undertaking the watershed planning process. In addition to watershed characteristics, river geomorphology parameters, such as channel length, channel slope, channel roughness, channel form and cross section are usually necessary for hydrologic analysis, planning, and management [6].

In this study, the geomorphologic parameters of a basin called Damlıca are determined using geographic information systems.

\section{Area under consideration}

\subsection{Damlica basin}

Studied basin (shown in Fig. 1) is on the Çatalca and Kumburgaz highway, $9 \mathrm{~km}$ from Kumburgaz and $51 \mathrm{~km}$ from İstanbul. The area of the basin is $8.26 \mathrm{~km}^{2}$. The 1:25000 topographic map of the basin was used. In ranking waterways, there are two second order branches, connected to Damlica stream. Damlica

* corresponding author; e-mail: agunal@gantep.edu.tr stream is then connected to Tepecik stream and flows into the Büyükçekmece lake. The outlet of the basin is at $41^{\circ} 06^{\prime} 04^{\prime \prime}$ North latitude, $28^{\circ} 25^{\prime} 00^{\prime \prime}$ East longitudes. Elevation above the sea level is $110 \mathrm{~m}$.

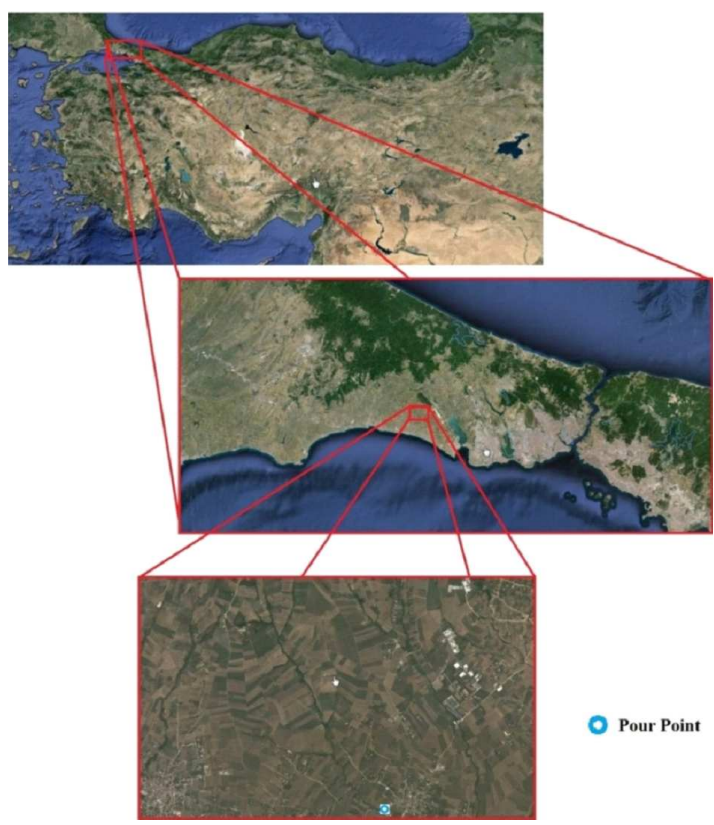

Fig. 1. Damlica basin.

\subsubsection{Topographic map of Damlica basin}

The topographic map of the Damlica basin is given in Fig. 2. The area of Damlica basin according to the topographic map is $8.26 \mathrm{~km}^{2}$ and it is $7.63 \mathrm{~km}^{2}$ according to GIS. There are three precipitation recording gauges. The runoff of the basin was measured by onestage recording gauge, installed on a triangular weir, with average width of $184 \mathrm{~m}$, over the main waterway in the outlet of the basin. $98.5 \%$ of the basin is covered with vertisol great soil group and $1.5 \%$ of the basin is covered with non calcic brown great soil group. All of the catchment area is used as a dry farming area. 


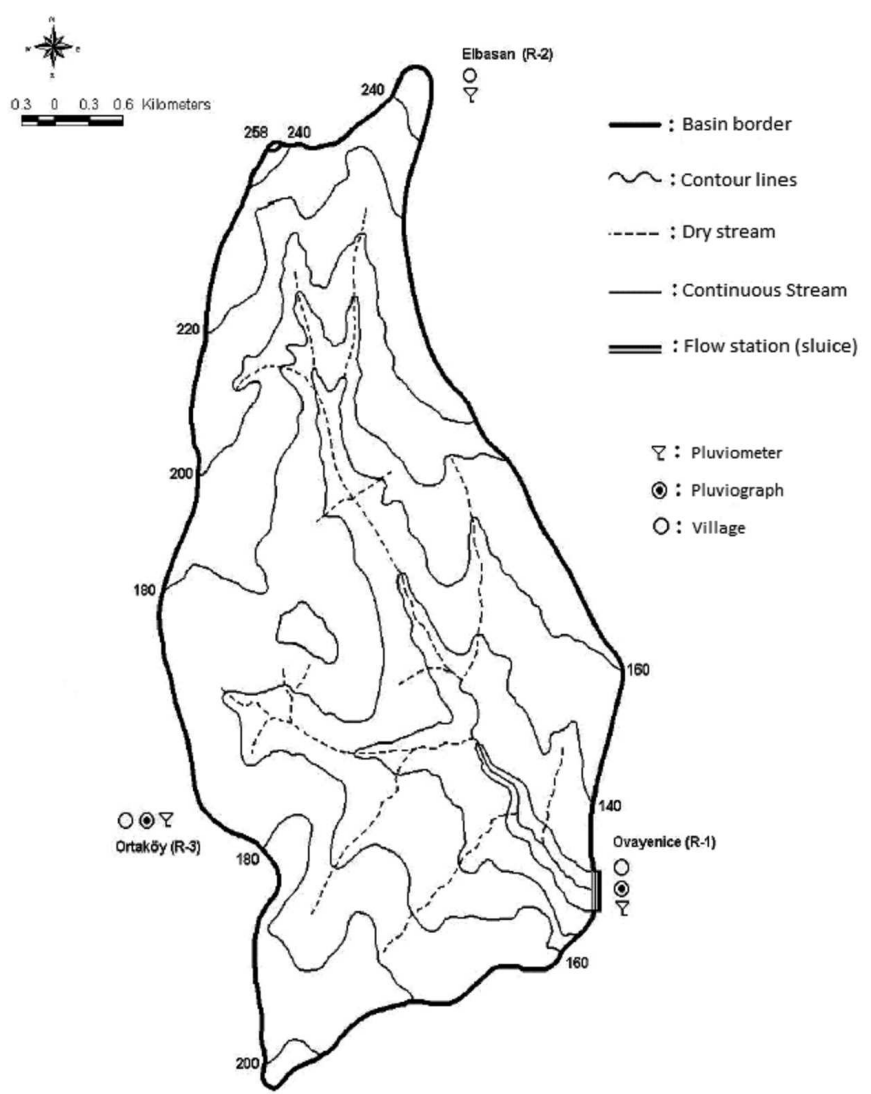

Fig. 2. Topographic map of the Damlıca basin.

\subsubsection{Digital elevation model (DEM) of Damlica basin}

The digital elevation model (DEM) of Damlica basin was downloaded from the Aster Global Digital Elevation Model (Aster GDEM) web site. It contains digital information and can be read only using ArcGIS programs. These programs extract the related information from the DEM map.

ArcGIS computer program is capable of calculating the geomorphologic parameters of the selected basin. A geographic information system, or GIS, is a computerized data management system used to capture, store, manage, retrieve, analyze, and display spatial information. In this study, DEM was loaded into the ArcGIS program. The morphologic parameters of the Damlica basin were calculated using ArcHydro tool of ArcGIS program. ArcHydro is a set of data models and tools that operate within ArcGIS to support geospatial and temporal data analyses. ArcHydro can be used to delineate and characterize watersheds in raster and vector formats, define and analyze hydro-geometric networks, manage time series data, and configure and export data to numerical models.

In this study, ArcGIS computer program was used to calculate the geomorphologic parameters of the Damlica basin. The computer program has produced digital map of Damlica stream basin, as shown in Fig. 3.

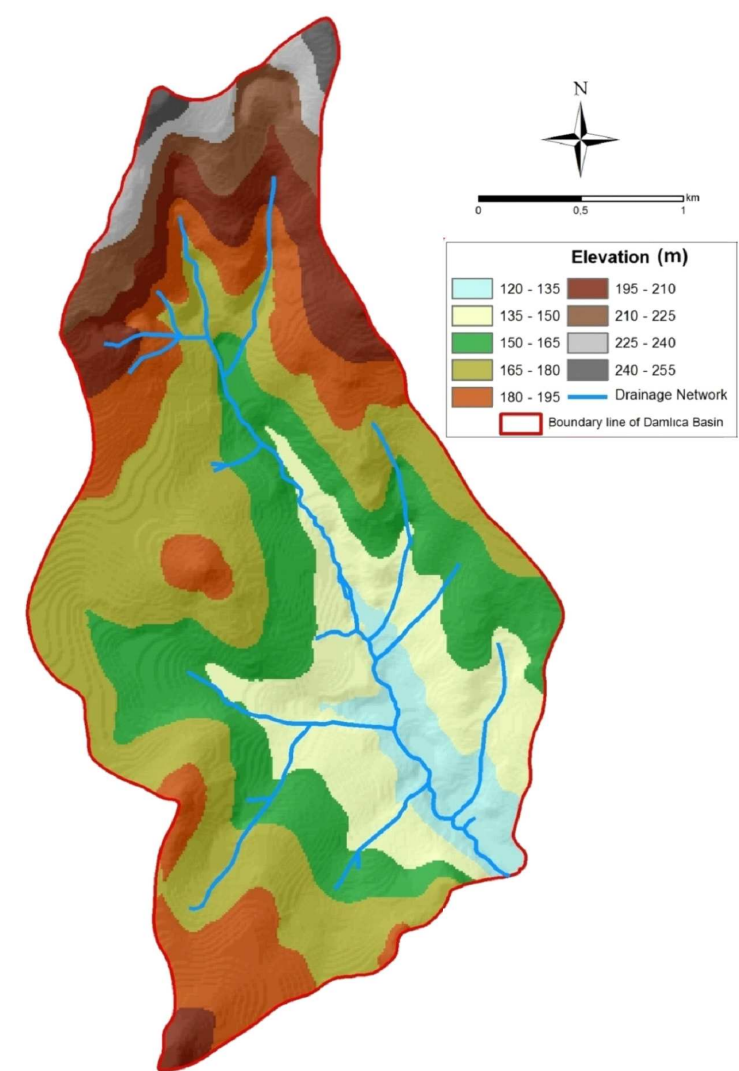

Fig. 3. Digital map of Damlıca basin.

\section{Results}

By processing DEM using GIS, more accurate results were obtained about watershed delineation, discretization and parameterization, than those based on topographic maps. Table shows the comparison of geomorphologic parameters (basin area, basin perimeter, basin length, river length, fineness ratio and main channel slope) of Damlica basin obtained using both ArcGIS and topographic map. Absolute errors for the geomorphologic parameters are also given in the last column of the Table. It is seen that absolute errors for all geomorphologic parameters are small. Therefore, ArcGIS values of geomorphologic parameters can be safely used instead of topographic map values.

\section{Conclusions}

By processing DEM using GIS applications, more accurate results of watershed delineation, descritization and parameterization were obtained, compared to results obtained using a topographic map.

Accurate river-basin delineation was obtained, thus accurate morphometric calculations were performed for the area under study. This study can be integrated with the Internet GIS, to obtain real-time hydrological data and information which will be very useful in monitoring water resources in the region under study. 
TABLE

Geomorphologic parameters of Damlıca basin obtained using ArcGIS and topographic map.

\begin{tabular}{|c|c|c|c|c|}
\hline $\begin{array}{c}\text { Geomorphologic } \\
\text { parameters }\end{array}$ & Definition & $\begin{array}{c}\text { ArcGIS } \\
\text { values }\end{array}$ & $\begin{array}{c}\text { Topographic } \\
\text { map values }\end{array}$ & $\begin{array}{c}\text { Absolute } \\
\text { error }\end{array}$ \\
\hline Basin area & $\begin{array}{l}\text { The total area projected upon a horizontal plane, contributing over- } \\
\text { land flow to the stream segment of the given order and all segments } \\
\text { of lower order. }\end{array}$ & $7.63 \mathrm{~km}^{2}$ & $8.26 \mathrm{~km}^{2}$ & $0.63 \mathrm{~km}^{2}$ \\
\hline Basin perimeter & $\begin{array}{l}\text { The length measured along the divide of the drainage basin as pro- } \\
\text { jected on the horizontal plane of the map. }\end{array}$ & $13.4 \mathrm{~km}$ & $13.10 \mathrm{~km}$ & $0.3 \mathrm{~km}$ \\
\hline Basin length & $\begin{array}{l}\text { The longest dimension of a basin parallel to the principal drainage } \\
\text { line. }\end{array}$ & $4.2 \mathrm{~km}$ & $4.1 \mathrm{~km}$ & $0.1 \mathrm{~km}$ \\
\hline River length & The length of main channel & $4.8 \mathrm{~km}$ & $4.35 \mathrm{~km}$ & $0.45 \mathrm{~km}$ \\
\hline$L_{c a}$ & The length from the basin outlet to a point adjacent to the centroid. & $1.9 \mathrm{~km}$ & $1.78 \mathrm{~km}$ & $0.12 \mathrm{~km}$ \\
\hline Fineness ratio & The ratio of channel length to the length of basin perimeter & 0.36 & 0.33 & 0.03 \\
\hline Main channel slope & $\begin{array}{l}\text { Slope of a line drawn along the measured profile, that has the same } \\
\text { area as the one under the observed profile. }\end{array}$ & 0.034 & 0.0189 & 0.0151 \\
\hline
\end{tabular}

\section{References}

[1] Ch.-Y. Chen, F.-Ch. Yu, Geomorphology 129, 387 (2011).

[2] F. Olivera, D. Maidment Water Resour. Res. 3, 1155 (1999).

[3] M.E. Noorbakhsh, M.B. Rahnama, S. Montazeri, J. Appl. Sci. 5, 455 (2005).
[4] Y. Seaedrashed, A. Guven, Water Resour. Manag. 27, 209 (2013).

[5] Z.X. Xu, K. Ito, G.A. Schultz, J.Y. Li, J. Comput. Civil Eng. 15, 217 (2001).

[6] M. Karamouz, F. Szidarovszky, B. Zahraie, Water Resources Systems Analysis, CRC Press, USA 2003. 